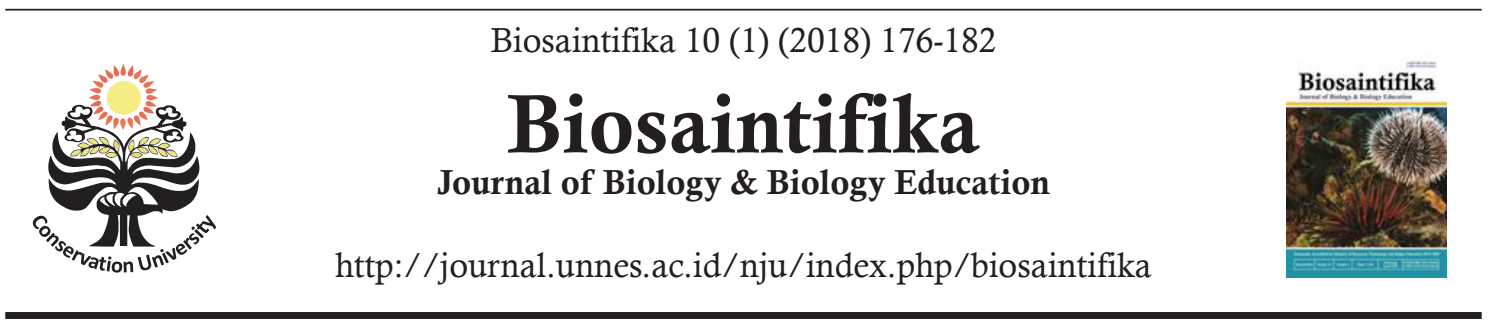

\title{
Biodiversity of Termites and Damage Building in Semarang, Indonesia
}

\author{
${ }^{\square}$ Niken Subekti, Bambang Priyono, Afrin Nur Aisyah
}

DOI: 10.15294/biosaintifika.v10i1.12832

Department of Biology, Faculty of Mathematics and Natural Sciences, Universitas Negeri Semarang, Indonesia

\section{History Article}

Received 11 September 2017 Approved 27 March 2018

Published 30 April 2018

\section{Keywords}

Biodiversity; Build-

ing damage; Residence

Construction; Termites

\begin{abstract}
Termites cause a lot of damage and big losses for building components, especially those made of wood. High population growth and rapid infrastructure development in Semarang city affect the natural habitats of termites. This phenomenon changes the termites' behavior of foraging in buildings. Semarang city has humidity, temperature, and altitude that allows termites to live and breed well. The purpose of this study was to determine the types of termites living in building in Semarang city as well as the level of attacks on housing. This research was conducted in nine residential buildings in Semarang City. The research was carried out with two methods: building inspection and wood-feeding method by using Pinus mercusii wood measures $2 \mathrm{~cm} \times 2 \mathrm{~cm} \times 46 \mathrm{~cm}$. The results found four types of termites that attack wood feeds namely Macrotermes gilvus, Microtermes inspiratus, Odontotermes javanicus, Coptotermes curvignathus and Cryptotermes sp.. Based on interviews and building inspection, it was known that the condition of the building in the category of "moderate" was occupying the most position (74.44\%), good (17.78\%) and lightly damaged (7.78\%). From the causes of damage to building components, it can be concluded that the level of termite attack against damage to residential buildings in Semarang city $44.58 \%$. Cross-tabulation analysis of Chi-Square shows that there is a correlation between age and treatment with damage to the building. Futher, the finding can be used as baseline information for further scientific investigation for effective termites control on residential building components.
\end{abstract}

\section{How to Cite}

Subekti, N., Priyono, B., \& Aisyah, A. N. (2018). Biodiversity of Termites and Damage Building in Semarang, Indonesia. Biosaintifika: Journal of Biology \& Biology Education, 10(1), 176-182.

(C) 2018 Universitas Negeri Semarang

$\triangle$ Correspondence Author:

D6 Building Floor 1 Jl. Raya Sekaran-Gunungpati Semarang 50229, Indonesia

E-mail: nikensubekti@yahoo.com

p-ISSN 2085-191X

e-ISSN 2338-7610 


\section{INTRODUCTION}

Semarang city is the capital of central Java province and one of the metropolitan cities in Indonesia. It has temperatures ranging from 26.6$29.2{ }^{\circ} \mathrm{C}$, with air humidity ranging in $76 \%$ and altitude of 0.75 to 348 masl (BPS, 2016). High population growth and rapid infrastructure development in this city is an influential factor causing a great disturbance to the natural habitat of termites. When termites lose their natural food sources in nature or the soil surface, they will ultimately look for food sources contained in buildings. This causes termites to become a potential threat to buildings (Subekti, 2010).

Termites are insects that cause a lot of damage to wood building (Priadi et al., 2010). Termites can eat cellulose derivatives such as furniture, furnishings, fabrics, paper and all articles containing cellulose (Subekti, 2016). Factors that may affect termite infestations in buildings include building components and furnishings which are made of wood, areas surrounding buildings with a high humidity, wooden building components directly related to soil, piles of wood, and materials containing cellulose (Savitri et al., 2016). The intensity of termite attack and the amount of damage generated can cause high economic losses and tend to increase from year to year (Arinana et al., 2016). According to Nandika et al. (2016), economic losses from termites attack in residential buildings in Indonesia was estimated at $\mathrm{Rp}$ 8.7 trillion in 2015.

This research was conducted to know the type of termites and the level of attacks on residential buildings in Semarang City, so it can be known how many attacks of termites occured in all buildings. This study area includes termite diversity, the intensity of damage to residential buildings and the relationship between age and maintenance performed on buildings against the extent of the damage.

The result of research can be used as baseline information for further scientific investigation for effective termites control on residential building components

\section{METHODS}

The location of the sampling was done on nine residences in Semarang city namely Sadeng, Semarang Indah, Bringin, Sukorejo, Srondol, Ngijo, Gombel and Pudak Payung. The study was conducted for four months, covering sampling in the field followed by identification in Bio- logy Laboratory, Biology Department, Faculty of Mathematics and Natural Sciences, Universitas Negeri Semarang.

The instruments used were specimen tube, questionnaire, Lux meter, Thermo hygro, label paper, microscope, Tho determination key book (1992), stationery, small shovel, some Demetra testers, photo camera, waterproof plastic, Global Positioning System (GPS), Petri dish. The materials used are Pinus mercusii wood with size $2 \mathrm{~cm}$ x $2 \mathrm{~cm}$ x $46 \mathrm{~cm}, 70 \%$ alcohol, termite specimen, soil sample.

Sampling method in this research was done by using purposive sampling technique with cross-sectional approach. The research was carried out in two methods: inspection and woodfeeding method. The research procedure was collection and identification of specimen, intensity analysis of damage of building, analysis of soil characteristic, and measurement of temperature, humidity, and light intensity.

\section{Collection and Specimen Identification}

The stake was made from $P$. mercusii wood, both the ends of the stake are painted to be distinguished from environmental conditions (ASTMD 1758-08 2008). The study used 180 stakes (20 stakes in each residence). Stakes were placed in a vertical position with an estimated half under the soil and half above the soil and planted for 2-3 months. Termite sampling was done by inspecting 90 buildings (10 buildings for each residence) with looking to the mark of termite attack that found on building component.

The termite samples from the soldier caste found were inserted into a collection bottle containing $70 \%$ alcohol and then were photographed using a stereo microscope. The sample was identified by reference to the book titled Termite of

\section{Peninsular Malaysia from Tho (1992). Intensity of Building Damage}

Analysis of damage intensity in the building was done by interview and inspecting the building by taking samples of 10 buildings from each residence so that there were 90 buildings as samples. This inspection was conducted on the main part of the building such as roof, foundation, wall frame, ceiling, walls, sills, floors, drainage of the yard, and utility The value of the degree of damage to buildings is presented in Table 1 .

Weighting techniques was needed to calculate the value of robustness building. Weighting techniques in each component group can be seen in Table 2. 
Niken Subekti et al. / Biosaintifika 10 (1) (2018) 176-182

Table 1. The Intensity of Building Damage

\begin{tabular}{|c|c|c|}
\hline $\begin{array}{l}\text { The Building } \\
\text { Condition }\end{array}$ & Score & Information \\
\hline Good & 5 & $\begin{array}{l}\text { The components of the } \\
\text { building are still well } \\
\text { functioning and there } \\
\text { is a maintenance on a } \\
\text { regular basis. }\end{array}$ \\
\hline Moderate & 4 & $\begin{array}{l}\text { The building compo- } \\
\text { nents are still well func- } \\
\text { tioning although there } \\
\text { is no maintenance on a } \\
\text { regular basis. }\end{array}$ \\
\hline $\begin{array}{l}\text { Low Dam- } \\
\text { age }\end{array}$ & 3 & $\begin{array}{l}\text { Components of the } \\
\text { building are still func- } \\
\text { tioning, but }<10 \% \text { of the } \\
\text { parts are experiencing } \\
\text { symptoms of damage } \\
\text { (weathered, cracked, at- } \\
\text { tacked by termites, dis- } \\
\text { coloration, etc.). }\end{array}$ \\
\hline $\begin{array}{l}\text { Medium } \\
\text { Damage }\end{array}$ & 2 & $\begin{array}{l}\text { Components of the } \\
\text { building is still function- } \\
\text { ing, but } 10 \%-40 \% \text { of } \\
\text { them are experienced } \\
\text { functional damage } \\
\text { (weathered, cracked, at- } \\
\text { tacked by termites, dis- } \\
\text { coloration, etc.) }\end{array}$ \\
\hline $\begin{array}{l}\text { High Dam- } \\
\text { age }\end{array}$ & 1 & $\begin{array}{l}\text { As much as } 40 \% \text { of the } \\
\text { building components } \\
\text { have functional damage } \\
\text { (weathered, cracked, at- } \\
\text { tacked by termites, dis- } \\
\text { coloration, etc.). }\end{array}$ \\
\hline
\end{tabular}

Sources: Suryadi (2005)

The building robustness value was calculated according to the following formula:

$\operatorname{VR}(\%)=\mathrm{x} 100 \%$

Information:

VR $=$ Value Robustness building $(\%)$

Determination of categories of building conditions is grouped into five classes of conditions, depending on the final percentage of robustness values obtained. Category of building robustness values and predicates are presented in Table 3.
Table 2. Quisionnaire weighing technique on each component of construction

\begin{tabular}{lccc}
\hline $\begin{array}{l}\text { Object of } \\
\text { Research }\end{array}$ & Rating \% & $\begin{array}{c}\text { Score } \\
(1-5)\end{array}$ & $\begin{array}{l}\text { Rating } \\
\text { x score }\end{array}$ \\
\hline Roof Work & 27 & & \\
Foundation & 21 & & \\
Wall Frame & 19 & & \\
Ceiling & 10 & & \\
Wall & 9 & & \\
Frame/door & 6 & & \\
leaves & 4 & & \\
Floor & 3 & & \\
Drainage & 1 & & \\
System & 100 & \\
Utilities & & \\
Total &
\end{tabular}

Source: Suryadi (2005)

Table 3. Category of building condition values

\begin{tabular}{cl}
\hline $\begin{array}{c}\text { Value of Building Robust- } \\
\text { ness (\%) }\end{array}$ & \multicolumn{1}{c}{ Category } \\
\hline $81-100$ & Good \\
$61-80$ & Moderate \\
$41-60$ & Low Damage \\
$21-40$ & Medium Damage \\
$0-20$ & High Damage \\
\hline
\end{tabular}

Source: Depkimpraswis (2003)

\section{Analysis of soil characteristics}

Analysis of soil character was to know the texture, moisture content, $\mathrm{pH}$, and C-organic content. Soil samples in each residence were taken in two depths of $0-20 \mathrm{~cm}$ and $20-40 \mathrm{~cm}$ so that there were nine soil samples at $0-20 \mathrm{~cm}$ depth and nine soil samples at $21-40 \mathrm{~cm}$ depth (total of 18 samples).

Measurement of air temperature, humidity, and light intensity. Measurements were conducted three times in each residence $(07.30$ WIB, 12.30 WIB, and 16.30 WIB) (Arinana et al., 2014).

\section{RESULTS AND DISCUSSION}

The diversity of Termites

Based from the result 180 stakes were 
planted and 90 inspected building at 9 residence spread in Semarang City, as many as 47 stakes were found by termites and damage from termite attack was found in all buildings, so total of termite attack that found in the stake or building as many as 137 termite attack.

The result from termite identification was found five species that was Coptotermes curvignathus (43.8\%), Macrotermes gilvus (18.25\%), Microtermes inspiratus (10.94\%), Odontotermes javanicus $(2.12 \%)$ and Cryptotermes sp. (24.82\%). The termite species found consisted of three families namely Rhinotermitidae, Termitidae and Kalotermitidae. Presentation of termitidae attacked there are $43.8 \%$ for Rhinotermitidae, Termitidae $31.39 \%$ and Kalotermitidae $24.81 \%$. According to Nandika et al. (2003), family Termitidae and Rhinotermitidae is a family group that mostly attacked the building of several major cities in Indonesia. Presented Termite species found can be seen in Figure 1.

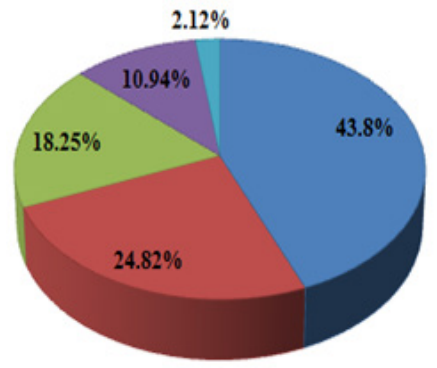

-Coptotemes cuovignathus -Cryptotermes sp. -Macrotenmes gilvus -Microtermes inspiratus -Odontotermes javaricus

Figure 1. Percentation of five termite spesies found in nine residential buildings of Semarang City

\section{The frequency of damage to buildings}

The conducted analysis to know the damage of the building covers the main parts of the building consisting of the roof, foundation, wall frame, ceiling, wall, sills, floor, drainage yard and utility (Puspantoro, 1996). The condition of residential buildings is presented in Figure 2 .

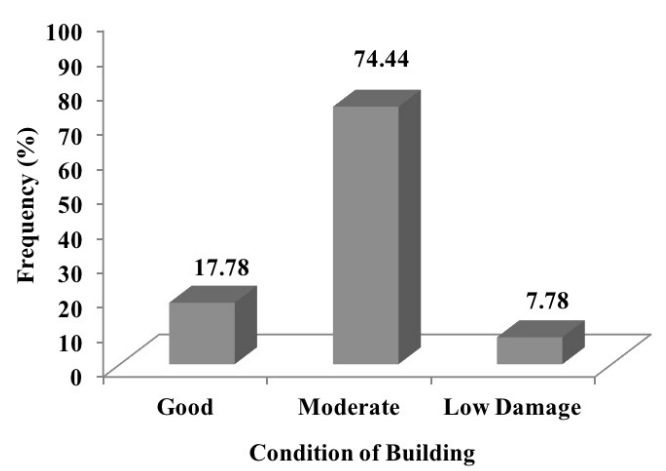

Figure 2. The condition of buildings on residences based on their damage
The results of interviews and inspections (Figure 2) show that the inspected building conditions consist of good, moderate and low damage. Moderate categories was occupying the most position that is $74.44 \%$, because the maintenance is not done regularly, so there is still much damage to the building component. Presentation of Good building condition was $17.78 \%$ because maintenance carried out on a regular basis. The condition of the building is low damaged $7.78 \%$, the results due to lack of maintenance periodically, maintenance was done only as necessary so that there was a lot of damage to building components.

The decrease in the quality of buildings can also occur due to the unwillingness of the building users to do maintenance (Dardiri, 2012). Interview results known that the maintenance performed at buildings is usually a periodical painting in one to five years and for treatments on building components that are the most widely done are care on the sills, doors, and windows are attacked by termites.

\section{Types and Form of Building Damage}

Factors that cause damage to the building are in the form of biological, mechanical, and physical factors. The most biological factors that cause damage to buildings are termites, beetles, and mosses. The mechanical factor is the damage caused by the static and dynamic force. Forms of damage are like cracks and broken. The physical factor is climate-induced damage such as temperature and humidity. Shape damage is the color change of wood, color fading in the paint, and peeling on paint (Watt, 1999). The frequency of damage can be seen in Figure 3.

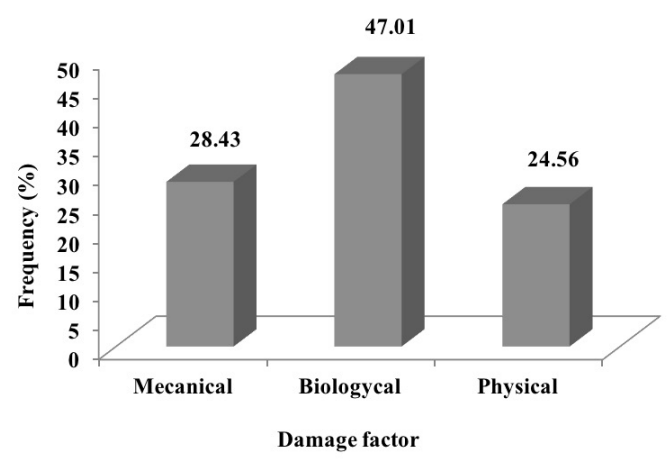

Figure 3. Frequency of damage in residential building caused by three main factors

From the result of the inspection, the condition of the building shows that the cause of damage of building component are the biological factor by $47.01 \%$, mechanical factor by $28.43 \%$, 
and physical factor by $24.56 \%$. Building components from the highest to the lowest frequency of damage are roof $(23.58 \%)$, wall $(21.32 \%)$, ceiling $(19.06 \%)$, window and door frames $(16.32 \%)$, floor (10.18\%), and wall frame (4.20\%). The most dominated biological factor is termite attack. Tarumengkeng (2000) stated that over the last twenty years, termites are the most disturbing factor of wood and building destruction. The termite attack occurs because the types of wood used as a building material in general are the class III of wood type or low-grade class.

\section{Frequency of termite attack}

The results of the inspection showed that the frequency of damage caused by termites and non-termites (beetle, moss, cracks/breaks, flaking paint and discoloration). Termites attaked is $44.58 \%$ and non-termites is $55.48 \%$. The frequency of termites attack on damage buildings can be seen in Figure 4.

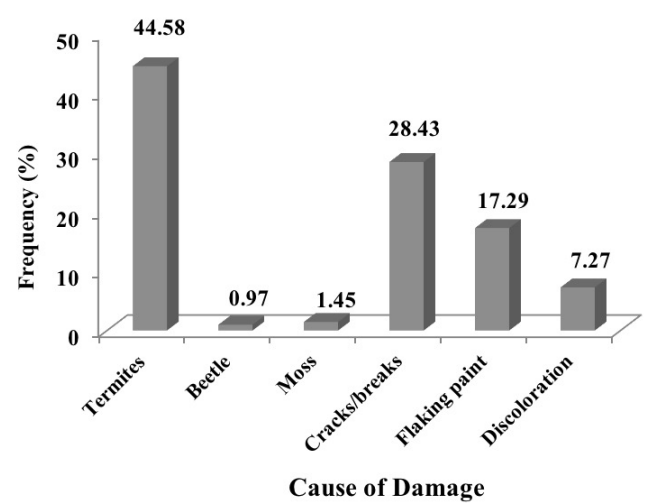

Figure 4. Frequency of termites and non-termites attack on damage buildings

Most termite attacks cause damage to building components. The levels of termite attacks occur in building components are: door frames and windows by $34.90 \%$, roof by $31.16 \%$, ceiling by $11.59 \%$, floor by $9.42 \%$, wall by $11.95 \%$, and wall frame by $3.26 \%$. The attack is caused by termites Coptotermes spp. and Cryptotermes sp.

Subterranean termites of the genus Coptotermes are important urban pest insects in tropical countries (Lee, 2002; Lee et al., 2007). This kind of termite has the impact of damage on building and higher ability to attack buildings than other termites. Prasetyo \& Yusuf (2005) stated that Coptotermes is a "destroying termite" that causes the most violent attack level. The workers of the genus Coptotermes foraging underground and move to rooftops through covered tunnels built along the vertical surfaces of materials (Gentz et al., 2008).
Cryptotermes have distinctive characteristics of other types of termites. They are commonly found in Indonesia and are known as pests for humans. Cryptotermes sp. do not require humid conditions, so that, they can attack building components even thought the humidity is low as in the frame and window. They have pellets as their excrement which are accumulated under the infested wood (Indrayani et al., 2017)

\section{Soil Analysis}

Soil analysis results showed that C-organic content ranged from $0.83-3.18 \%$ which was included in low to high category, $\mathrm{pH}$ ranged from 6-7.5 which was a neutral $\mathrm{pH}$, Water content ranged from 15.63 to $26.79 \%$, salinity of $0.22-0.69 \mathrm{~ms} /$ $\mathrm{cm}$, and soil texture at the research site comprised clay loam (38.9\%), loam (22.2\%), sandy silt-loam $(16.7 \%)$, clay loam $(11.1 \%)$, sandy clay-loam (5.5\%), and sandy clay (5.5\%).

The organic C-content present in the soil is sufficient to support the process that takes place in the soil. Such a C-organic content does not have a complex problem with chemical processes occurring in the soil (Hardjowigeno, 2003). According to Lee and Wood (1971), land in which there is a termite activity has a high content of organic matter.

In general, termites like the soil type that contains a lot of clay because it has a high content of organic material and fine texture. Termites do not like sandy soil types because they have low organic matter (Nandika et al., 2016). This is in accordance with the results of soil physical analysis that the texture of the soil in the residential buildings of Semarang is clay loam with medium texture and loam so that the termites can live well.

Termites can live and breed in soils with low acid content (Kurniawan et al., 2015). In accordance with the results of the analysis, the $\mathrm{pH}$ condition of Semarang City is suitable for termites to live. Soil $\mathrm{pH}$ is important because soil and plant organisms are highly responsive to their chemical and environmental properties (Djaenudin et al., 2003). Dissolved nutrients can conduct electricity, so that, the more dissolved nutrients, the higher the electrical conductivity. This condition is often known as salinity.

\section{Analysis of temperature, humidity and light intensity}

Abiotic factors also affect the environment where living creatures live. Abiotic factors measured in this study include the intensity of light, temperature, and humidity. The measurement results can be seen in Table 4 . 
In Table 4. it is known that the measurement results are in accordance with optimum temperature and humidity conditions of termites. Measurement in the morning $(07.30 \mathrm{am})$ shows the temperature range between $32-34$, with range between $65-70 \%$ moisture, and light intensity of 5,010 lux. In daytime (12:30 pm), the temperature was $34-40$ the humidity was $47-54 \%$, and the light intensity was 13,388 lux. In the afternoon (16:30 $\mathrm{pm})$, the temperature was $31.5-33$, the moisture was $67-73 \%$ and the light intensity was 5,041 .

Table 4. Average light intensity, temperature and humidity

\begin{tabular}{lccc}
\hline Time & $\begin{array}{c}\text { Light } \\
\text { Intensity } \\
\text { (lux) }\end{array}$ & $\begin{array}{c}\text { Tempera- } \\
\text { ture () }\end{array}$ & $\begin{array}{c}\text { Humid- } \\
\text { ity (\%) }\end{array}$ \\
\hline Morning & 5,010 & $32-34$ & $65-70$ \\
Afternoon & 13,388 & $34-40$ & $47-54$ \\
Evening & 5,041 & $31.5-33$ & $67-73$ \\
\hline
\end{tabular}

The intensity of sunlight that ecosystems receive is an important determinant of primary productivity, which in turn can affect species diversity and nutrient cycles (Mokany et al., 2008). Termites are insects that have thin skin, susceptible to the dehydration process by wind/dry air so that the termites require a stable moisture (Subekti et al., 2008). This study showed that the temperature of Semarang city ranged between $32-38^{\circ} \mathrm{C}$ with humidity ranging from $50-70 \%$, so that the termites can live and grow well in the city of Semarang. This is in accordance with the statement of Nandika et al. (2016) that termites living at temperatures ranging from $15-38^{\circ} \mathrm{C}$.

\section{Influence of Age, Frequency of Maintenance, and Home Building Care}

The result of Cross-tabulation analysis shows that the relationship between age of the building with building condition is shown by the Chi-Square value of 18.114 at DF 4 (p-value $0,001<0.05$ ) which means that age of the building is significantly related to the building condition. Coefficient correlation of age of the building with the condition of the building is 0.409 . The number of buildings that are $<15$ years old is 12 or $13.3 \%$ of all buildings, seven of them $(58.3 \%)$ have a good conditions, $1(8.3 \%)$ of them is in low damage, and $4(33.3 \%)$ of them are in moderate conditions. The number of buildings aged of 15 to 30 years is 51 or $56.7 \%$ of all buildings, eight of them $(15.7 \%)$ are in a good conditions, while 3 of them $(5.9 \%)$ are in low damaged, and 38 of them $(78.4 \%)$ are in moderate conditions. The number of aged of $>30$ Years are as many as 27 or $30 \%$ of all buildings, one of them (3.7\%) is in a good condition, while 3 of them (11.1\%) are in a low damage, and as many as 23 or $85.2 \%$ of them are in moderate conditions. It shows that the older the building, the damage will be greater worse.

Relationship of maintenance with building condition of Chi Square value 11.702 at DF 2 (pvalue $0.003<0.05$ ) which means that building maintenance correlated significantly with the condition of the building. The maintenance of the building that was done affect for the condition of building. Treatment relationship with building condition of Chi Square value is 5.981 at DF 2 (p-value $0.050>0.05$ ) which means that building maintenance is not significantly related to the condition of the building.

The finding can be used as baseline information for further scientific investigation for effective termites control on residential building components.

\section{CONCLUSION}

Based on the results of research conducted in buildings in Semarang, it can be concluded that there are four types of termites at the research sites i.e. O. javanicus, M. gilvus, $M$. inspiratus C. curvignathus and Cryptotermes sp., which are included to Family Rhinotermitidae (43.8\%), Termitidae (31.39\%) and Kalotermitidae (24.81\%). From the causes of damage to building components, it can be concluded that the level of termite attack in buildings in in Semarang city is $44.58 \%$. The condition of the buildings in the study location was in moderate condition (74.44\%), good condition (17.78\%) and low damage condition (7.78\%).

\section{ACKNOWLEDGMENT}

A special thank to Biology mLaboratory, Biology Department, Faculty of Mathematics and Natural Sciences, Universitas Negeri Semarang for the facilities and all parties who are willing to assist in this research.

\section{REFERENCES}

[ASTM] American Society for Testing and Materials. (2008). Standard Test Method of Evaluating Wood Preservatives by Field Test with Stakes. American Society for Testing and Material. United States: ASTM D 1758-08

Arinana, N. F. H., Nandika, D., \& Prawitasari, W. A. (2014). Damage intensity of house building 
and termite diversity in Perumahan Nasional Bumi Bekasi Baru, Rawalumbu Bekasi. In The Utilization of Biomass from Forest and Plantation For Environment Conservation Efforts. Proceedings of the 6th International Symposium of Indonesian Wood Research Society, Medan, Indonesia.

Arinana, A., Aldina, R., Nandika, D., Rauf, A., Harahap, I. S., Sumertajaya, I., \& Bahtiar, E. T. (2016). Termite Diversity in Urban Landscape, South Jakarta, Indonesia. Insects, 7(2), 20

[BPS] Badan Pusat Statistika. (2016). Kabupaten Semarang

Dardiri, A. (2012). Analisis Pola, Jenis, dan Penyebab Kerusakan Bangunan Gedung Sekolah Dasar. Teknologi dan Kejuruan, 35(1), 71-80

[Depkimpraswil] Departemen Permukiman dan Prasarana Wilayah. (2003). Keputusan Menteri Permukiman dan Prasarana Wilayah tentang Pedoman Teknis Pembangunan Gedung Negara. PT Mediatama Saptakarya: Jakarta.

Djaenudin, D., Marwan, H., Subagyo, H., Mulyani, A., \& Suharta, N. (2003). Kriteria Kesesuaian Lahan Untuk Komoditas Pertanian. Bogor: Balai Penelitian Tanah. Pusat Penelitian Dan Pengembangan Pertanian. Departemen Pertanian

Gentz, M. C., Rubinoff, D., \& Grace, J. K. (2008). Phylogenetic Analysis of Subterranean Termites (Coptotermes spp., Isoptera: Rhinotermitidae) Indicates the Origins of Hawaiian and North American Invasions: Potential Implications for Invasion Biology. Proc. Hawaiian Entomol. Soc 40, 1-9.

Hardjowigeno, S. (2003). Klasifikasi Tanah dan Pedogenesis. Jakarta: Akademika Pressindo.

Indrayani, Y., Takematsu, Y., \& Yoshimura, T. (2017). Short Communication: Diversity and distribution of termites in buildings in Pontianak, West Kalimantan, Indonesia. Biodiversitas 18(3), 954957

Kurniawan S. R., Rudianda S., \& Mardhiansyah, M. (2015). Identifikasi Dampak dan Tingkat Serangan Rayap terhadap Bangunan di Kabupaten Kuantan Singingi. Jom Faperta, 2(2), 2-4

Lee, C. Y. (2002). Control of foraging colonies of subterranean termites Coptotermes travians (Isoptera:Rhinotermitidae) in Malaysia usinghexaflumuron baits. Sociobiology, 39(3), 411-412

Lee, C.Y., Vongkaluang, C., \& Lenz, M. (2007). Challenges to subterranean termite management of multi-genera faunas in Southeast Asia and Australia. Sociobiology, 50(1), 213-216

Mokany, A., Wood, J. T. \& Cunningham, S. A. (2008).
Effect of shade and shading history on species abundances and ecosystem processes in temporary ponds. Freshwater Biology, 53(10), 19171928.

Nandika, D., Rismayadi, Y. \& Diba, F. (2016). RAYAP Biologi dan Pengendaliannya, 2nd ed.; Mubin N. (Ed). Muhammadiyah University Press: Surakarta

Prasetyo, K.W. \& Yusuf, S. (2005). Mencegah dan Membasmi Rayap Secara Ramah Lingkungan dan Kimiawi. Bogor: Agromedia Pustaka Bogor.

Priadi, T., Nandika, D., Sofyan, K., Acmad \& Witarto, A. B. (2010). Biodeteriorasi Komponen Kayu Rumah di Beberapa Daerah Yang Berbeda Suhu dan Kelembabannya. Jurnal Ilmu dan Teknilogi Hasil Hutan, 3(1), 26-31

Prasetyo, K.W. \& Yusuf, S. (2005). Mencegah dan Membasmi Rayap Secara Ramah Lingkungan dan Kimiawi. Bogor: Agromedia Pustaka Bogor.

Puspantoro, B. (1996). Konstruksi Bangunan Tidak Bertingkat. Yogyakarta: Universitas Atmajaya Yogyakarta.

Savitri, A., Martini \& Yuliawati, S. (2016). Keanekaragaman Jenis Rayap Tanah dan Dampak Serangan Pada Bangunan Rumah di Perumahan Kawasan Mijen Kota Semarang. Jurnal Kesehatan Masyarakat, 4(1), 101-103

Subekti, N. (2010). Characteristic of Population Subterranean Termites Coptotermes spp (Blattodea: Rhinotermitidae) and Its Attack Impact. Biosaintifika: Journal of Biology \& Biology Education, 2(2), 110-114

Subekti, N. (2012). Biodeteriorasi kayu pinus (Pinus merkusii) oleh rayap tanah Macrotermes gilvus Hagen (Blattodea: Termitidae). Bioteknologi, 9 (2), 57-65

Subekti, N. (2016). Rayap Arsitektur Bangunan Masa Depan. Surakarta: UNS Press.

Subekti, N., Duryadi, D., Nandika, D., Surjokusumo, S. \& Anwar, S. (2008). Distribution and Morphology Characteristic of Macrotermes gilvus Hagen in The Natural Habitat. Jurnal Ilmu dan Teknologi Hasil Hutan, 1(1), 27-33.

Suryadi, D. (2005). Kekokohan konstruksi bangunan Sekolah Dasar Negeri (studi kasus: Kec. Cibarusah Kab. Bekasi). Skripsi. Bogor: Universitas Pakuan

Tarumingkeng, R. (2000). Manajemen Deteriorasi Hasil Hutan. Jakarta: Ukrida Press.

Tho, Y. P. (1992). Termites of Peninsular Malaysia. Kuala lumpur: Forest Researcah Institute Malaysia, Kepong.

Watt, D. S. (1999). Building Pathology: Principle and Practice. Inggris (GB): Cambridge University Press. 